1,2ZIMÁNYI RÓBERT G. - 'GÉCZI GÁBOR

\title{
SPORTESEMÉNYEK JOGOS JEGYÁRAI, KÖZÉPPONTBAN AZ IGAZSÁGOSSÁGGAL
}

- A 2019-ES JÉGKORONG-VILÁGBAJNOKSÁG (VILÁGCSOPORT) JEGYÁRAINAK ELEMZÉSE

JUSTIFIABLE TICKET PRICES FOR SPORT EVENTS, FOCUS ON JUSTICE

\section{- ANALYSIS OF THE 2019 IIHF ICE HOCKEY WORLD CHAMPIONSHIP TICKET PRICES}

\author{
${ }^{1}$ Testnevelési Egyetem \\ ${ }^{2}$ EVOPRO Group Sportegyesület - Elnök \\ zimanyi.robert@evopro-sc.com
}

\begin{abstract}
Absztrakt
A legmagasabb osztályú jégkorong-világbajnokságok (Világcsoport) a kiemelt sportesemények közé tartoznak. A nagyobb érdeklődés egy lehetséges mérőszáma a nézői látogatottság. Mi határozza meg a helyszíni nézők számát? Egy sportesemény látogatottsága nagymértékben attól függ, hogyan határozzák meg a szervezők a hivatalos jegyárakat. Jogosak a jegyárak? A jogosság alapjának az arisztotelészi legfőbb erényt vesszük: az igazságosságot. A tanulmány az eseménnyel kapcsolatban felmerülő alábbi igazságosságelméleteket vizsgálja: evolucionista felfogás, Arisztotelész igazságossággal kapcsolatos elmélete, Bentham és Mill utilitarista felfogása, libertarianizmus, meritokrácia, egalitarianizmus és a pozitív diszkrimináció elmélete. A tanulmányban bemutatott igazságosságelméletek alapján el kell dönteni, mely elméletet követik a szervezők adott mérkőzések jegyárainak meghatározásával kapcsolatban, és miért. A tanulmányban vizsgált sportesemény a 2019-es jégkorong-világbajnokság (Világcsoport). Miként tudtak a szervezők igazságos jegyárakat megállapítani a csoportmérkőzésekre és az egyenes ági kieséses szakaszra? Akármelyik igazságosságelméletet is követik, annak a rendezvény lényegi természetével (téloszával) is összhangban kell lennie. A kutatás során megállapíthatjuk, a tanulmányban vizsgált mindegyik igazságosságelmélet megjelenik - azonban egyik sem tud egyedüliként és kizárólagosan megvalósulni a jégkorong-világbajnokság hivatalos jegyáraival kapcsolatban. Összességében elmondhatjuk, a szervezők
\end{abstract}


által megállapított hivatalos jegyárak meghatározása jogosnak és igazságosnak tekinthető: csak attól függ, melyik igazságosságelméletet tekintik a szervezők indokoltnak adott mérkőzések jegyáraival kapcsolatban, és miért.

Kulcsszavak: jégkorong, télosz, jegyárak, igazságosságelméletek

\begin{abstract}
The IIHF (International Ice Hockey Federation) ice hockey world championships are among the major sport events. A possible measure for the level of interest is the audience's attendance. What is the key driving factor behind the number of on-site viewers? The attendance of the sport event depends largely on the official ticket prices, which are defined by the organizers. Are the ticket prices justifiable? The basis of legitimacy and the righteousness is the Aristotelian supreme virtue, the justice. The study examines the following theories of justice in connection with the event: evolutionist conception, Aristotle's justice theory, Bentham and Mill's utilitarian perception, libertarianism, meritocracy, egalitarianism, and the theory of the positive discrimination. Based on the presented theories of justice, it must be decided, which theories of justice do the organizers follow regarding the determination of ticket prices for the individual games, and why? In the study, the examined sport event is the 2019 IIHF Ice Hockey World Championship. How could the organizers determine fair and just ticket prices for the group matches and for the knock-out system? Whichever justice theory is followed, it must be consistent with the essential nature (telos) of the event. During the research, we can conclude: each of the examined theories of justice appears - however, none can be realized alone and exclusively in relation to the ice hockey world championships official ticket prices. In summary: the determination of the event's official ticket prices (by the organizers) is considered to be fair; it just depends on which justice theory is considered legitimate and justified in relation to certain individual games' ticket prices, and why.
\end{abstract}

Keywords: ice hockey, telos, ticket prices, theories of justice 


\section{Témaválasztás indoklása}

Napjaink nagy sporteseményei, különösen a világbajnokságok komoly figyelmet kapnak, amelyeket különböző médiacsatornákon keresztül lehet (akár elő közvetítésekkel is) nyomon követni világszerte. A jégkorong-világesemények, kiemelten a legmagasabb osztályú világcsoportos világbajnokságok (továbbiakban világbajnokságok) kiemelt sporteseménynek számítanak. Ez meglátszik az érdeklődők számából is, mind a képernyők előtt, mind a helyszínen lévő nézők tekintetében. Utóbbi esetben meghatározó tényezők a jegyárak, hogyan képzik azokat a szervezők, és ezen árakhoz hogyan viszonyulnak a mérkőzésekre potenciálisan kilátogatók. A jegyárak meghatározása komoly kérdés, az érdeklődés mellett ez a fő tényezője a helyszíni nézőszámnak. Minden egyes sportesemény sikere attól függ, mennyire tekinthető minőséginek adott rendezvény. A minőség egyik erényalapú megközelítése alapján az igazságosság kulcsszerepet játszik. A jégkorong-világbajnokságokon is ugyanúgy fontos az igazságosság kérdésköre, mint ahogy az élet más területein. Hogyan lehet igazságos jegyárakat meghatározni? Milyen szempontokat kell a szervezőknek figyelembe venniük? A tanulmány ezen előzőleg felsorolt kérdésekre igyekszik szakszerű válaszokat adni. A megválaszoláshoz összegyűjtöttünk igazságosságelméleteket, emellett megvizsgáltuk a 2019-es szlovákiai jégkorong-világbajnokság (Világcsoport) mérkőzéseire szóló belépőjegyeket.

A kérdéskör részletes vizsgálata előtt egy fontos megjegyzés: a szervezők általi jegyár-meghatározásnak az alapja nem az igazságosság, vagy legalábbis napjaink gyakorlatában nem ezt tekintik elsődlegesnek - sokkal inkább gazdasági érdekek húzódnak meg a háttérben, középpontban a hasznosság maximalizálásával, azaz a cél minél nagyobb bevétel generálása a jegyeladásokból. Azonban emellett a sport értékeit és téloszát is figyelembe kell venni, azaz a gazdasági érdekek nem játszhatnak kizárólagos szerepet, gondoljunk itt arra, ha irreálisan magas jegyárakat határoznának meg, akkor elsősorban nem a szakma művelői és elhivatott képviselői ülnének a nézőtéren, akiknek igazán szólna sportszakmailag az esemény, hanem azon nézők, akik ugyan meg tudják fizetni a magasabb jegyárakat, azonban semleges érzésűek a jégkoronggal kapcsolatban; akik kizárólag a szórakozás miatt vesznek jegyet a sporteseményre, nem törődve a jégkorong mint sportág mikrokultúrájával. A gazdasági érdekek mellett egy (verseny)sporteseményhez hozzátartoznak a nézők is, így a "sportszakmai és sportgazdasági kereslet-kínálat" elvének megfelelve olyan jegyárakat kell meghatározni, amelyek mellett megvalósulhat teltházas sportrendezvény; megfelelő létszámú közönség buzdíthatja (remélhetőleg sportszerűen) a versengő és győzelemre törő csapatokat. 


\section{Bevezetés}

A sporteseményeket különbözőképpen lehet csoportosítani és elemezni, eszerint megkülönböztethetünk sportegyesületi analógiának megfelelően verseny-, szabadidős és vállalati sportegyesületeket, sporttevékenységeket és sporteseményeket (Zimányi, Vermes, 2016). A jégkorong-világbajnokság mindenképpen versenysport-eseménynek számít, így ennek megfelelően is elemezzük a világeseményt és annak jegyárait. Ha a jégkorong-világbajnokság téloszát szeretnénk megtudni, először is definiálni kell a télosz fogalmát. A télosz fogalmát Arisztotelésznél fedezhetjük fel, aki szerint meg kell találnunk a célt, a lényegi természetet (Aristotle, 2011). Ezen gondolatból kiindulva, mi lehet a jégkorong világbajnokság célja, lényegi természete, azaz télosza? Mivel világversenyről van szó, ezért a versenysport téloszának is meg kell felelni. Ezalatt az alábbi (a tudomány és közvélemény számára is könnyen elfogadható) tézist értjük: a sport normatív értékeinek betartása mellett, amely értékekre jelen tanulmányban nem térünk ki (Simon, Torres, Hager, 2015), megnyerni egy adott versenyt "egyenlő kiinduló feltételek mellett", a feltételeknek megfelelően legyőzni minden ellenfelet, és így a világ legjobbjának, azaz világbajnok nemzetnek lenni. $\mathrm{Ha}$ minden előző feltétel teljesül, akkor a versenysporton belül a jégkorong-világbajnokság télosza is érvényesül.

Mindezt hogyan tudjuk összekapcsolni a jegyárakkal? A nagyobb érdeklődés egy lehetséges mérőszáma a nézői látogatottság. Ezt, azaz az optimalizált helyszíni nézőszámot tekintjük a jegyértékesítés téloszának, amelynek szintén meg kell felelni. Mi határozza meg a helyszíni nézők számát? Egy sportesemény látogatottsága nagymértékben attól függ, hogyan határozzák meg a szervezők a hivatalos jegyárakat. Jogosak a jegyárak? A jogosság alapjának az arisztotelészi legfőbb erényt vesszük: az igazságosságot. Ahogy az élet bármely területén, úgy a sportban is törekszünk az igazságosságra. Hogyan lehet igazságosan meghatározni a jegyárakat? Egy versenysport-esemény célja, hogy az érdeklődők is meg tudják nézni a helyszínen a mérkőzéseket. Csak így lehet társadalmi esemény egy sportverseny (Földesiné, Gál, Dóczi, 2010). Ehhez hozzáférhető és megfizethető jegyárakat kell megállapítani. Így mindkettő télosznak (világbajnokság és jegyárak meghatározása) meg kell felelnünk a minőség érdekében. Azonban minden mérkőzés jegyára igazságosan van meghatározva? A válasz: igen, de csak akkor, ha előfeltételként teljesül az adott esemény, jelen esetben a jégkorong világbajnokság és a jegyárak meghatározásának télosza. Hiszen ha a télosz nem teljesül, nem is beszélhetünk minőségi sporteseményről, így igazságosságról sem, amely a minőség egy lehetséges aspektusa. Azonban, hogy pontosabban megértsük az igazságot, meg kell vizsgálni a felmerülő és lehetséges igazságosságelméleteket. 


\section{Általános igazságosságelméletek - a jégkorong-világbajnokság jegyáraira fókuszálva}

Mit jelent az „igazság"? Válasz: ha úgy osztjuk el a rendelkezésre álló elemeket helyes módon, ahogyan megérdemeljük (Sandel, 2009). Felmerülhet a kérdés: mit érdemlünk meg, és miért? Fontos az elkövetkezőkben az értelmezés szempontjából, hogy morális oldalról közelítsük meg a kérdést. A következőkben felsorolunk olyan igazságosságelméleteket, amelyek szerepet játszhatnak a jégkorong-világbajnokság jegyáraival kapcsolatban. A tanulmány terjedelmére való tekintettel nem minden igazságosságelméletet elemzünk, valamint az elméleteket nem elemezzük minden részletre kiterjedően, hiszen a tanulmány a jégkorong-világbajnokság jegyáraival kapcsolatos igazságosságra koncentrál. Így a vizsgált igazságosságelméletek felsorolása után konkrétan elemzésre és kifejtésre kerülnek a tanulmány szempontjából releváns elméletek és azok aspektusai.

Az evolúciós igazságosságot úgy értelmezhetjük, mint az evolúciós elmélet adaptálását az igazságosságra vonatkozóan. Azaz elsődleges a külső és belső feltételekhez történő alkalmazkodás (Darwin, 2015). Alkalmazkodás során (esetünkben egy jégkorong-világbajnokság jegyáraival kapcsolatban) úgy kell meghatározni a mérkőzésekre szóló jegyárakat, hogy ahhoz alkalmazkodni tudjanak az érdekelt felek, ezáltal befolyásolni tudják az adott mérkőzés helyszíni nézőszámát. Arisztotelésznél az igazságosság "legfőbb erényként" jelenik meg, az arisztotelészi igazságosság a kiválóságra épít. Arisztotelésznél az igazságosság kardinális erény: az embereknek megadni azt, ami jár nekik, amit érdemelnek - és mindez a kiválóság alapján határozható meg, ráadásul a többiek így is a legjobb helyzetbe kerülnek (Aristotle, 2011). Az egalitarianizmus szerint egyenlőségre kell törekednünk, egyenlő mindenki - a meritokrácia ezzel ellentétben az elért eredményeken alapuló rendszert hirdeti igazságosságként. A pozitív diszkrimináció is lehet egy igazságossági aspektus, amely alapján valamely szempont szerint pozitívan megkülönböztetünk valakiket. Ilyen lehet többek között a sokszínúség előmozdítása (Sandel, 2009). A sport területére úgy lehet adaptálni, hogy a szervezők vagy a Nemzetközi Jégkorong Szövetség (IIHF) szabadkártyákat ad „kisebb jégkorongnemzeteknek” a világbajnokságon való indulásra, vagy a szervező országnak adott „hazai jog” gyakorlásaként az indulhat a világbajnokságon, kvalifikációtól és világranglista-helyezéstől függetlenül. Mindez összefüggött a jegyárakkal? Alkalmaztak a szervezők pozitív diszkriminációt a hazai csapat mérkőzéseinek jegyáraival kapcsolatban? Erre a kérdéskörre is kitérünk a tanulmány során. Nem tartozik a kutatáshoz, de fontosnak tartjuk megemlíteni a diszkrimináció kapcsán, hogy a sportnak mindenféle negatív diszkriminációt el kell utasítania, sőt: fel is kell lépni ellene - ezt a sport télosza is megköveteli. Azaz nem lehet a jegyárakat bármilyen negatív diszkriminációs szempont alapján meghatározni (nem is lenne etikus). Az utilitarizmus szerint a haszonelvűség a lényeg, ennek képviselője, Bentham a boldogság maximalizálásával foglalkozott. Szerinte az élvezetnek nagyobbnak kell lennie, 
mint a fájdalomnak (Bentham, 1996). Mill is megvédte a bírálókkal szemben a haszonelvűséget, etikájában az egyéni szabadságjogok és a haszonelvűség összevetése és összeegyeztetése szerepel a középpontban: az emberek bármit szabadon megtehetnek, amit csak akarnak, ennek egy feltétele, hogy nem árthatnak vele másoknak - és az állam sem korlátozhatja a szabadságjogokat (Mill, 1989). Mill filozófiájában kulcsszerepet kapnak a magasabb rendű élvezetek. Szerinte az alacsonyabb és magasabb rendű élvezetek között különbséget kell tenni. A magasabb rendű élvezetek erősebb, hosszabban tartó élvezeteket eredményezhetnek, amely boldogsághoz vezet. A libertarianizmus képviselői a "szabadelvúséget" és a korlátozásmentes piacot hirdetik, és az állami beavatkozás elutasítását. Az emberi szabadság nevében szabadon cselekedhetünk bármit, hiszen a szabadság mindannyiunk alapvető joga (Sandel, 2009).

\section{Célkitűzés: igazságosságelméletek alkalmazhatósága és kutatásmódszer- tan}

A tanulmány a világbajnoksággal és a hozzá tartozó jegyárakkal kapcsolatban a fent említett igazságosságelméleteket vizsgálja. Természetesen léteznek további igazságosságelméletek is, amelyeket nem elemzünk jelen tanulmány keretein belül, mert nem tartjuk relevánsnak a kutatási téma kapcsán, azaz a jégkorong-világbajnokságok jegyáraival kapcsolatban. Ilyen például a kanti igazságosság, Kant moralitással, racionalitással és szabadsággal kapcsolatos nézetei vagy Rawls egyenlőséggel kapcsolatos igazságosságelmélete, amely utóbbi elméletet csak megemlítünk a csoportkör utáni, egyenes ági kieséses rendszer fejezeténél. A méltányosság és a hendikep kérdésköre is ide tartozik (Sandel, 2009), 1-1 példával alátámasztjuk, miért nincs ezen utóbbi igazságosságelméletnek létjogosultsága a tanulmány kapcsán. Az adott esemény téloszának megfelelő igazságosságelméletet lehet csak alkalmazni, ha minőségi sporteseményről, ezen belül minőségi jégkorong-világbajnoki jegyárakról szeretnénk beszélni.

A tanulmányban bemutatott igazságosságelméletek alapján el kell dönteni, mely elméletet követik a szervezők egy adott világbajnoki mérkőzés jegyárainak meghatározásával kapcsolatban, és miért. Mely elméletek alkalmazása indokolt a jégkorong-világbajnokság jegyáraival kapcsolatban? Egyetlen igazság létezik, csak az a kérdés, melyik elméletet kövessük. Olyan igazságosságelméletet kell követni, amely az esemény téloszának is megfelel (ez kizáró kritérium), így az előzőekben felsorolt elméleteket kell rendszerezni és megvizsgálni a világbajnoki jegyárak kapcsán. Ahhoz, hogy egy teljes és valós képet tudjunk kapni, a vizsgált igazságosságelméletek feldolgozása mellett esettanulmányként összegyűjtöttük és elemeztük a 2019-es jégkorong-világbajnokság legmagasabb osztályának, a Világcsoport csoportmérkőzéseinek meghatározott jegyárait. Azaz a tanulmányban vizsgált sportesemény a 2019-es jégkorong-világbajnokság legmagasabb osztálya, a Világcsoport, amelynek Szlovákia ad otthont, és a 
szervezők már 2018 szeptemberében meghatározták a jegyárakat (http://2019. iihfworlds.com/en/tickets/). Miként tudtak a szervezők igazságos jegyárakat megállapítani? A vizsgálat az egy mérkőzésre szóló belépőjegyekre (individual games) terjed ki, és a hivatalos, szervezők által deklarált jegyárakra vonatkozik, azaz a viszonteladói kereslet-kínálatra épülő utilitarianizmust kizártuk.

A következőkben leírjuk, milyen eredményeket hozott kutatásunk a 2019es jégkorong-világbajnokság Világcsoportjának jegyáraival kapcsolatban. Természetesen minden jégkorong-világbajnokság más és más, azonban a nemzetközi szakszövetség égisze alatt rendezik meg évről évre a sportági világbajnokságot, így az itt kapott eredmények nemcsak a 2019-es szlovákiai világbajnokságra igazak és érvényesek, hanem általánosságban véve (kisebb módosításokkal és eltérésekkel) a jelenlegi jégkorong-világbajnokságok tendenciáira is. Természetesen tisztában vagyunk azzal, hogy változások bármikor bekövetkezhetnek, kutatásunk a jelenlegi helyzetet és a 2019-es jégkorong-világbajnokságra (Világcsoport) meghatározott mérkőzésenkénti jegyárakat elemzi, kutatja és vizsgálja.

\section{Eredmények: a csoportmérkőzések hivatalos jegyárainak igazságossága}

Ahogy korábban említettük, a szervezők már 2018-ban meghatározták a mérkőzések jegyárait és játékrendjét is, így már a világbajnokság kezdete előtt előre lehet tudni: melyik válogatott, kivel, hol és mikor fog megmérkőzni. Ennek megfelelően lettek meghatározva a szervezők által a hivatalos jegyárak is. A következő táblázat a 2019-es jégkorong-világbajnokság (Világcsoport) mérkőzéseinek jegyárait tartalmazza, nemzetekre lebontva.

\begin{tabular}{|l|l|l|l|}
\hline Nemzetek & Helyszín & $\begin{array}{c}\text { I. kategória } \\
\text { jegyár (euró) }\end{array}$ & $\begin{array}{l}\text { II. kategória } \\
\text { jegyár (euró) }\end{array}$ \\
\hline Oroszország (RUS) & Pozsony & 60 & 45 \\
\hline Norvégia (NOR) & Pozsony & 35 & 25 \\
\hline Csehország (CZE) & Pozsony & 75 & 60 \\
\hline Svédország (SWE) & Pozsony & 60 & 45 \\
\hline Svájc (SUI) & Pozsony & 60 & 45 \\
\hline Olaszország (ITA) & Pozsony & 20 & 10 \\
\hline Lettország LAT) & Pozsony & 35 & 25 \\
\hline Ausztria (AUT) & Pozsony & 20 & 10 \\
\hline Finnország (FIN) & Kassa & 60 & 45 \\
\hline Kanada (CAN) & Kassa & 60 & 45 \\
\hline USA (USA) & Kassa & 60 & 45 \\
\hline Szlovákia (SVK) & Kassa & 75 & 60 \\
\hline Dánia (DEN) & Kassa & 35 & 25 \\
\hline
\end{tabular}




\begin{tabular}{|l|l|l|l|}
\hline Franciaország (FRA) & Kassa & 20 & 10 \\
\hline Németország (GER) & Kassa & 35 & 25 \\
\hline Nagy-Britannia (GBR) & Kassa & 20 & 10 \\
\hline negyeddöntő (QF) & Pozsony & 100 & 70 \\
\hline negyeddöntő (QF) & Pozsony & 100 & 70 \\
\hline negyeddöntő (QF) & Kassa & 100 & 70 \\
\hline negyeddöntő (QF) & Kassa & 100 & 70 \\
\hline elődöntő (SF) & Pozsony & 200 & 160 \\
\hline elődöntő (SF) & Pozsony & 200 & 160 \\
\hline 3. helyért (BMG) & Pozsony & 180 & 145 \\
\hline döntő (FINAL) & Pozsony & 350 & 300 \\
\hline
\end{tabular}

előre meghatározott fix jegyárak, csapatoktól függet-

1. táblázat

A 2019-es jégkorong-világbajnokság (Világcsoport) mérkőzéseinek jegyárai nemzetekre lebontva

Saját táblázat

Adatok forrása: http://2019.iihfworlds.com/en/tickets/

Láthatjuk, két helyszínen: Pozsonyban (Bratislava) és Kassán (Kosice) rendezik a világbajnokságot, és a helyszíntől függetlenek a jegyárak, azaz ebből a szempontból egalitarianista elvű a rendszer - valamint abból a szempontból is, hogy ugyanannyi csoportmeccset játszanak Pozsonyban és Kassán is. Az igazságosság értelmezése előtt egy fontos megállapítás: a jegyárak úgy kerültek meghatározásra, hogy a két, egymás ellen játszó csapathoz tartozó jegyárak közül a „magasabbat” alkalmazzák a szervezők (http://2019.iihfworlds.com/en/ tickets/). A kutatás során végig kellett nézni az összes csoportmérkőzés jegyárait (a II. kategóriás jegyárakat vizsgálva), és a legalacsonyabb 10 eurós jegyárból kiindulva (Olaszország, Ausztria, Nagy-Britannia, Franciaország) meg lehetett határozni a további mérkőzések jegyárait. A II. kategóriás jegyárakat vizsgálva így jutottunk el a „25 eurós” (Norvégia, Lettország, Dánia, Németország), a "45 eurós" (Oroszország, Svédország, Svájc, Finnország, Kanada, USA), majd végül a legmagasabb "60 eurós” (Szlovákia és Csehország) nemzetekig. Láthatjuk, 4 nemzet tartozik a legalacsonyabb jegyárhoz, további 4 válogatott a második legalacsonyabb jegyárhoz, míg a következő, egyben a második legmagasabb jegyár-kategóriánál 6 nemzetet figyelhetünk meg, míg a legdrágább jegyárak 2 nemzetet érintenek: a házigazda Szlovákiát és a velük szomszédos Csehországot. Az előzőekben felvetődött néhány elem, most nézzük sorra, mi alapján igazságosak a csoportmérkőzések jegyárai.

Az evolúciós igazságosságelmélet szerint elsődleges a külső és belső feltételekhez történő alkalmazkodás (Darwin, 2015). Azaz alkalmazkodni kell a szervezők jegyáraihoz (a szervezőknek nem kell megindokolniuk, miért ezeket az összegeket határozták meg). Azonban a fenti télosz alapján a szervezőknek is úgy kell meghatározni a mérkőzésekre szóló jegyárakat, hogy alkalmazkodni tudjanak az érdekelt felek, ezáltal befolyásolni tudják egy adott mérkőzés hely- 
színi nézőszámát. A nézők is tudják befolyásolni azzal, ha nem mennek el a meghatározott jegyárakon, így a szervezőknek csökkenteniük kell az árakat a télosz teljesülése miatt - optimális esetben telt házas mérkőzések alakulnak ki. Erre lehetőségük van egészen a világbajnokság kezdetéig, sőt: az adott mérkőzésekre szóló belépőket még aznap, a kezdő sípszóig is módosíthatják.

Az arisztotelészi igazságosságelmélet a kiválóság alapján különböztet meg, ráadásul ezen elv szerint a többiek is így kerülnek a legjobb helyzetbe (Aristotle, 2011). Azaz a "kiválóbb csapatok" mérkőzéseire magasabbak a jegyárak. De mi alapján lehet kiváló egy nemzet? A kérdést a meritokráciával együtt kezeljük, amely az elért eredményeken alapuló rendszert hirdeti mint igazságosság. Itt is felmerülhet a kérdés, mi alapján érdemlik meg egyes csapatok, hogy magasabbak a jegyárak. Mind az arisztotelészi kiválóság, mind a meritokrácia esetében a világranglista-helyezéseket vettük alapul, és eszerint vizsgáljuk a kérdést. Ha a világranglista-helyezéseket vesszük alapul (és hiszünk is a valós számítási módszerükben), akkor az előkelőbb helyen álló nemzetek komolyabb játékerőt képviselnek, ebből következően kiválóbbak és jobbak az elért eredményeik, azaz indokoltak a magasabbak jegyárak (https://www.iihf.com/en/worIdranking). Azonban valóban csak a világranglista-helyezés számít a jegyárak kapcsán? Láthatjuk, hogy a világranglista-helyezések nem feleltethetőek meg minden esetben a meghatározott jegyárakkal, nem egyenesen arányosak. Azaz nem csak a világranglista az igazságosság alapja a jegyárak meghatározásánál. Nézzük konkrétabban a világranglista-helyezéseket és a hozzájuk tartozó jegyárakat, amelyet a 2. táblázat tartalmaz! A nemzetek világranglista-helyezés szerint növekvő sorrendben szerepelnek. 


\begin{tabular}{|l|l|l|l|}
\hline Nemzetek & $\begin{array}{c}\text { Világranglista } \\
\text { helyezés }\end{array}$ & $\begin{array}{c}\text { I. kategória } \\
\text { jegyár (euró) }\end{array}$ & $\begin{array}{l}\text { II. kategória } \\
\text { jegyár (euró) }\end{array}$ \\
\hline Kanada (CAN) & 1. & 60 & 45 \\
\hline Svédország (SWE) & 2. & 60 & 45 \\
\hline Oroszország (RUS) & 3. & 60 & 45 \\
\hline USA (USA) & 4. & 60 & 45 \\
\hline Finnország (FIN) & 5. & 60 & 45 \\
\hline Csehország (CZE) & 6. & 75 & 60 \\
\hline Svájc (SUI) & 7. & 60 & 45 \\
\hline Németország (GER) & 8. & 35 & 25 \\
\hline Norvégia (NOR) & 9. & 35 & 25 \\
\hline Szlovákia (SVK) & 10. & 75 & 60 \\
\hline Lettország (LAT) & 11. & 35 & 25 \\
\hline Dánia (DEN) & 12. & 35 & 25 \\
\hline Franciaország (FRA) & 13. & 20 & 10 \\
\hline Ausztria (AUT) & 17. & 20 & 10 \\
\hline Olaszország (ITA) & 19. & 20 & 10 \\
\hline Nagy-Britannia (GBR) & 22. & 20 & 10 \\
\hline
\end{tabular}

2. táblázat

A 2019-es jégkorong-világbajnokság (Világcsoport) résztvevőinek világranglista-helyezése és mérkőzéseikre a jegyárak

Saját táblázat

Adatok forrása: http://2019.iihfworlds.com/en/tickets/ és https://www.iihf.com/en/worldranking

A 2019-es világbajnokság résztvevői nem feltétlenül szerepelnek a világranglistán is a legjobb 16 között. Ahogy látjuk az 1-13. helyezettek kivívják a jogot a részvételhez, a világranglista 14., 15. és 16. helyezettje azonban nem szerzett jogot az indulásra, helyettük a világranglista 17., 19. és 22. szerepel.

Ahogy a táblázat is mutatja, a jegyárak meritokratikusak és arisztotelészi kiválóság alapúak is egyben. Igaz, hogy megfigyelhető egy csökkenő tendencia, azonban mégsem tökéletesen valósulnak meg. Két nemzet lóg ki a szigorúan monoton csökkenő sorból. Az egyik a világranglista 6. helyezett Csehország, a másik a házigazda, világranglista 10. helyezett Szlovákia. A legdrágább jegyárak meghatározása azonban nem függ össze azzal, hogy adott nemzet határos-e Szlovákiával. Ugyanis Ausztria is határos a rendező országgal, mégis a legalacsonyabb jegyár (holtversenyben) az osztrák csapaté, ahogy világranglista-helyezésük is hátrébb van. Az már számíthat, hogy a szomszédos Csehországgal korábban egy államot alkottak Csehszlovákia néven (ezen felvetés és összefüggés igazolására jelen keretek között nem tér ki a tanulmány). A másik kérdés, hogy a szervezők hol húzták meg a határokat. Akkora a különbség a világranglista 7. (Svájc) és 8. helyezettje (Németország) között, hogy a jegyárakon is látszódnia kellene? Valamint a jegyárkülönbségek és a nemzetek teljesítménye 
között van párhuzam? Ha majdnem feleannyiba kerül egy mérkőzésre a jegy, akkor az elért eredmények és a kiválóság alapján fele olyan jó a nyújtott teljesítmény is? Erre nehéz válaszolni, nem is igazán lehet mérni, így a kutatás ezen kérdéskör vizsgálatára nem terjed ki.

Az utilitarizmus szerint haszonelvűségre kell törekedni. A benthami filozófiát követve a boldogság, az élvezet maximalizálása a cél (Bentham, 1996). Ennek megfelelően úgy lettek meghatározva a jegyárak, hogy a mérkőzések a legnagyobb élvezetet tudják nyújtani, azaz a legnagyobb hasznot a szervezőknek. Minél „kiválóbb” csapat játszik, annál magasabb a jegyár (az előző kifejtésből látszódik, hogy nem minden esetben), amely nagyobb hasznot, azaz bevételt generál a szervezőknek, csökkentve ezzel a kiadásokat. A szintén utilitarista Mill szerint az emberek bármit szabadon megtehetnek, amit csak akarnak, ennek egy feltétele, hogy nem árthatnak vele másoknak - és az állam sem korlátozhatja a szabadságjogokat (Mill, 1989). Azaz a szervezők szabadon megszabhatják a jegyárakat, csak ne ártsanak másoknak. Mit jelentenek a „mások"? Ha a többi csapatra gondolunk, akkor nem ártunk azzal, ha egy másik nemzet mérkőzésére olcsóbbak vagy drágábbak a jegyek, azonban ha a szurkolókra gondolunk, akkor nekik abban az értelemben ártanak, ha hazájuk vagy kedvenc csapatuk mérkőzésére drágábbak a belépőjegyek. Mill „magasabb rendű élvezetei" a mérkőzések nyújtotta élvezetnél figyelhetőek meg, amiért magasabbak lehetnek a jegyárak - azaz egyes válogatottak magasabb rendű élvezetet tudnak nyújtani a nézőknek a megfizetett jegyár ellenében. Azaz az utilitarianizmus benthami értelemben megvalósul, de milli értelemben csak részben; tehát részleges utilitarista igazságosság figyelhető meg a jegyárak kapcsán. Valamint az állam sem korlátozza a szervezők jogait, szabadon határozhatják meg a jegyárakat, azaz ebben az értelemben is igazságosnak mondható az utilitarista jegyár-meghatározás. Ez utóbbi mondattal át is térünk a libertarianizmusra, láthatjuk, van kapcsolat e két elmélet között.

A libertarianizmus eszméje a "szabadelvűséget" és a korlátozásmentes piacot hirdeti, valamint az állami beavatkozás elutasítását. Az emberi szabadság nevében szabadon cselekedhetünk bármit, hiszen a szabadság mindannyiunk alapvető joga (Friedman, 1962). Azaz az utilitarianizmushoz hasonlóan a szervezők szabadon cselekedhetnek, azaz szabadon meghatározhatják a jegyárakat. A korlátozásmentes piac jelenti a kereslet-kínálat egyensúlyát. A szervezők azon az áron határozzák meg a jegyárakat (kínálják), amelyen a későbbi helyszíni nézők megveszik (kereslet) - ezt azt is jelenti, hogy meg kell vizsgálniuk, mekkora az a maximális ár (rezervációs ár), amelyet a szurkolók hajlandóak kifizetni egy-egy mérkőzés helyszíni megtekintéséért és szurkolásáért. Azaz ezen elmélet szerint az Olaszország-Ausztria II. árkategóriás jegyet nem tudnák 10 eurónál drágábban eladni úgy, hogy telt ház legyen. Ellenben ha Szlovákia vagy Csehország játszik, az ugyanolyan árkategóriás jegy 60 euró. Ez az árképzés is megfelel a kereslet-kínálat törvényének. Az állami beavatkozás elutasítása ott figyelhető meg, hogy a szervezők maguk képzik adott mérkőzésekre az árakat. Az utilitarianizmus és a libertarianizmus egyaránt megfigyelhető az alábbi 
esetben: a szervezők egy mérkőzésre a csapatokhoz tartozó jegyárak közül a „magasabbat" alkalmazzák (http://2019.iihfworlds.com/en/tickets/). Azaz például a Svájc-Olaszország mérkőzésre a Il. kategóriás belépőjegy 45 euró. Svájc mérkőzéseire 45 eurót állapítottak meg a szervezők, míg Olaszország esetében 10 eurót. Ha egymás ellen játszanak, akkor a magasabb ár lép életbe, azaz a "svájci jegy", amely 45 euró az adott kategóriában. A szervezők úgy gondolják, hogy így realizálhatják a legnagyobb hasznot (élvezet és boldogság maximalizálásának analógiája); a jegyárak alapján magasabban jegyzett válogatott mérkőzésére (amely nagyrészt a világranglista-helyezéssel is összefügg) az ellenfél szurkolói is rászánják azt a többletösszeget, illetve magasabb áron is el fog kelni az adott mérkőzésre szóló belépőjegy a kereslet-kínálat törvényei alapján.

$\mathrm{Az}$ egalitarianizmus szerint egyenlőségre kell törekednünk, mindenki egyenlő. Ezen igazságosságelmélet is csak részben valósul meg, hiszen a 2. táblázatból kiderül: vannak olyan nemzetek, akik mérkőzéseire megegyeznek a jegyárak, azonban nem minden esetben. Nehéz is lenne egyenlőséget találni, hiszen egy csapatot nem ugyanazon játékosok alkotják, nem mindenki ugyanannyi játékpercet tölt a pályán egy csapatból, nem ugyanazok az ellenfelek. Ha minden feltétel egyenlő volna, még a világranglista-helyezés is, akkor lehetne minden mérkőzésnek ugyanolyan jegyára. De akkor mi a helyzet Szlovákia és Csehország esetével? Itt térünk rá a következő igazságosság-elméletre, a pozitív diszkriminációra.

A pozitív diszkrimináció is lehet egy igazságossági aspektus, amely alapján valamely szempont szerint pozitívan megkülönböztetünk "valakiket". A "sandeli elvek" szerint ilyen az előítéletek korrigálása, a múlt bűneinek megbocsátása és a sokszínűség előmozdítása (Sandel, 2009). Az első kettő elv nem tartozik a versenysport kérdéséhez, a harmadik esettel érdemes foglalkozni. Hogyan lehet értelmezni a sokszínűség előmozdítását? Például minél több földrész képviseltesse magát. Összeegyeztethető mindez a télosszal? A válasz: igen. Gondoljunk egyéb sportági kvalifikációkra, például a csapatsportágakra: labdarúgás, kézilabda, kosárlabda. Mely válogatottak indulhatnak a világbajnokságon? A kontinensek bajnokai, illetve akik a versenykiírásnak megfelelő helyen végeztek, így szintén jogosultak az indulásra (ez megfelel a versenysport téloszának, hiszen elért teljesítmény is van mögötte). A jégkorong esetében ez így van? A válasz: nem. Ebben a sportágban nincsenek kontinensenkénti kvalifikációk, hierarchikus osztályok (divíziók) vannak, feljutással és kiesési lehetőséggel (https://www. iihf.com/en/tournaments). Azaz nem azért nem szerepel a 2019-es világbajnokságon a világranglista 14., 15. és 16 . helyezettje, mert helyettük a 17. a 19. és a 22. helyezettje vesz részt a sokszínűség előmozdítása érdekében, hanem mert utóbbiak szereztek jogot (kvalifikációt) az indulásra. Ezen elvek tisztán meritokratikus és arisztotelészi kiválóságalapú megkülönböztetések a mindig jelen lévő evolúciós alkalmazkodás mellett - a versenyfeltételekhez való alkalmazkodás az indulási jog megszerzésére (Zimányi, Géczi, 2018/b). Így ha kizárólag a "sandeli elveket" nézzük, akkor nem beszélhetünk pozitív diszkriminációról. Ha elrugaszkodunk a "sandeli elvektől", akkor a hazaiak megkülönböztetése is 
lehet egy pozitív diszkrimináció (Zimányi, Géczi, 2018/b), az ő mérkőzésük érhet a legtöbbet a szervezők számára, ezért magasabbak a jegyárak is, így vannak a többiektől pozitívan megkülönböztetve (Csehország esetében ugyanez az elv nem állja meg a helyét). Valamint megemlítendő, hogy amelyik nemzet elnyeri egy világbajnokság rendezési jogát, azon nemzet abban az évben a legjobbak között szerepelhet, előző évi teljesítményétől függetlenül (meritokrácia- és arisztotelészi kiválóságalapú megkülönböztetés hiánya) - azaz érvényesül pozitív diszkrimináció, az más kérdés, mindez hogyan alakul a jegyárakra nézve (https://www.iihf.com/en/events/2019/wm/tournamentinfo/3951/tournament-info).

Rövid kitérésként csak megemlítjük a méltányosság egy példáját, hogy miért nem alkalmazható ezen igazságosságelmélet a jégkorong-világbajnokság jegyáraival kapcsolatban. Legyenek a többi nemzethez képest kedvezőbben a jegyárak csak azért, mert szomszédos országokról beszélünk? Vagy a gazdaságilag fejletlenebb országok szurkolói ingyen mehessenek be a mérkőzésekre? A szervezők természetesen megtehetnék, azonban ahogy az 1. táblázat mutatja, nem tették, a jegyárak függetlenek az országok földrajzi elhelyezkedésétől, valamint azok gazdasági helyzetétől, és minden egyéb méltányossági szemponttól azaz ezen igazságossági elv nem jelent meg a 2019-es világbajnokság kapcsán.

\section{Csoportmérkőzés utáni, egyenes ági kieséses rendszer mérkőzéseinek igazságos jegyárai}

Az 1. táblázat alapján megfigyelhető, a negyeddöntőket 2 helyszínen rendezik, míg az elődöntőktől a döntőig a mérkőzésekre kizárólag Pozsonyban kerül sor. Így a helyszíneket illetően egy részleges egalitarianizmus figyelhető meg, hiszen mindkét helyszínen játszanak mérkőzéseket, de összesen több mérkőzést játszanak Pozsonyban, mint Kassán. Mi lehet ennek az oka? A főváros nagyobb számú lakossága? Vagy a jégkorongaréna befogadóképessége a minél több néző befogadása érdekében? A válasz mindkettő kérdés alapján lehet igen, azonban ezen állításainkat jelen körülmények között nem támasztjuk alá kutatással (mivel nem tartozik szorosan a vizsgált területhez, így most megelégszünk ezen sejtéssel).

Az előző témakörhöz képest a legnagyobb különbség, hogy a sport természeténél fogva előre nem lehet tudni, melyik jégkorong-válogatott kivel, hol és mikor fog megmérkőzni - csak az elődöntőktől lehet tudni, hogy Pozsony a helyszín, de hogy mely nemzetek jutnak el odáig, csak a csoportmérkőzések utáni negyeddöntők során derül ki. A csoportmérkőzésektől függ, mely csapat melyik helyszínen fog játszani az egyenes ági kieséses szakaszban. A jegyárak azonban ezt a bizonytalan tényezőt nem követik, ahogy az 1. táblázat is mutatja - hiszen előre meg vannak határozva a szervezők által a kieséses mérkőzésekre szóló jegyárak, csak azt nem tudni, kik fognak játszani egymás ellen, így aki ezen kieséses mérkőzésekre belépőt vásárol, kockáztat, látja-e a kívánt nemzetet. Az 
egyenes ági kieséses rendszerbe a világbajnokságon részt vevő csapatok fele bejut, így 8 csapat folytatja a küzdelmet a végső célért, ahol már nincs hibázási lehetőség, azaz egy vereséggel véget érnek a küzdelmek, a csoportkörrel ellentétben, ahol lehet hibázni, azaz vereséget szenvedni (https://www.iihf.com/en/ events/2019/wm/tournamentinfo/3951/tournament-info).

Nézzük a jegyárak meghatározásának „,igazságait”! Az evolúciós szemléletet követve alkalmazkodni kell a körülményekhez, így a jegyárakhoz is. A szervezők az igényekhez és a fizetési határhajlandósághoz alkalmazkodva határozzák meg az árakat. A bizonytalan tényezőhöz nekik is alkalmazkodniuk kell: nem tudni, mely mérkőzésen kik fognak játszani, azonban az egyenes ági kieséses szakaszhoz úgy alkalmazkodnak, hogy ez már a "végjáték kezdete", és lesz elengedő igény a nézők részéről, valamint lehet egy sejtésük, mely nemzetek jutnak be a negyeddöntőbe, valamint figyelembe veszik, hogy a legjobb 8 csapat (akik továbbjutottak a csoportból) mérkőzéseire nagyobb lehet a kereslet, főleg úgy, hogy már nincs hibázási lehetőség (azaz nem lehet vereséget szenvedni ahhoz, hogy világbajnok legyen egy nemzet). Az érdekelt felek igényeit itt is szem előtt kell tartani, ehhez kell alkalmazkodni a jegyárak meghatározása kapcsán - megcélozva a minél több telt házas mérkőzést, amely az utilitarianizmussal mint a haszonmaximalizálással is összefügg.

Az arisztotelészi kiválóságalapú megkülönböztetés ezen fázisban is megjelenik. Azaz a szervezők úgy határozzák meg a jegyárakat, hogy mivel a "kiválóbb” nemzetek jutnak be a legjobb 8 közé az egyenes ági kieséses szakaszban, ezért a kiválóságnak megfelelő, magasabb jegyárakat határoznak meg. Ráadásul a kiválóság között is tesznek különbséget: az 1. táblázat alapján láthatjuk, az elődöntőkre (ha a II. árkategóriás jegyeket vizsgáljuk) több mint kétszeres áron van egy belépőjegy, mint a negyeddöntőkre. Ha tovább megyünk, a döntőre (ahová a teljesítmény alapján a két legkiválóbb jégkorongnemzet jut be) is közel kétszer akkora a jegyár, mint az elődöntőre. Egy "kakukktojás" figyelhető meg, a 3. helyért zajló mérkőzés. Miért 145 euró a II. kategóriás jegyár? Miért kevesebb, mint az elődöntőkre? Az arisztotelészi igazságosságelmélet szerint azért lehet olcsóbb a jegyár az elődöntőkhöz képest, mert az elődöntők vesztesei játszanak egymás ellen, amivel "kiválóságuk megítélése csökkenhet”. Azonban a jegyárak alapján kevesebb mint fele olyan kiválóak, mint akik legyőzték őket, és a döntőben a végső győzelemért játszhatnak? Nehéz mérni a kiválóságot, főleg úgy, hogy egy mérkőzés alapján dől el a továbbjutás, ahol az is elképzelhető, hogy a világranglista alapján gyengébb nemzet jut be a döntőbe, a jegyárak alapján azonban mégis őket tekinthetjük „kiválóbbnak" (az előre meghatározott árak alapján).

A meritokráciát ezen kérdéskörben hasonlóan kezeljük, mint az arisztotelészi kiválóságalapú igazságot. A meritokrácia esetében az elért eredményen alapuló rendszeren van a hangsúly, amely itt is megfigyelhető a jegyárak kapcsán: akik továbbjutnak az egyenes ági kieséses szakaszban, azok mérkőzéseire az elért eredményeik alapján magasabbak a jegyárak is. Az arisztotelészi eszméhez hasonlóan a 3. helyért zajló mérkőzés jegyára is az eredmények 
miatt alacsonyabb (nem tudtak bejutni a döntőbe), mint az elődöntők jegyárai. Itt is felmerülhet a kérdés az előző kérdéskörhöz hasonlóan: miért csökken a kiválóság és az elért eredmény? Megjegyezzük, hogy az elért eredmény „csökkenése" még valamelyest indokolt lehet, hiszen az elődöntős végeredmény alapján vereséget szenvedtek (rosszabb az eredményük legyőzöttjükkel szemben). Visszatérve a kérdéshez, ha bejutott valamelyik csapat az elődöntőbe, és ott vereséget szenved, ugyanúgy a legjobb 4 nemzet között marad a világbajnokságon, ezt nem vehetik el tőlük. Az ár ezt azonban nem tükrözi, hiszen az alacsonyabb, ez alapján az elért eredményük alacsonyabb, és a kiválóságuk is csökken. Természetesen nem egy mérkőzéstől függ az elért eredmény és a kiválóság, azonban a szervezőknek mikroszinten kell nézniük egy-egy világbajnokságot, azaz akik az elődöntőkben vereséget szenvedtek, azoknak az elért eredményük és kiválóságuk a megítélés alapján csökken, hiszen nem várják el tőlük már a végső győzelmet, valójában nem is lehet, mert nincs már lehetőségük megnyerni a világbajnokságot, a legjobb helyezés amit elérhetnek, a 3. hely, amely azonban szintén figyelemre méltó.

Utilitarista igazságosságot is megfigyelhetünk, hiszen a szervezők a haszonelvüség jegyében határoznak meg magasabb árakat, hiszen itt, az egyenes ági kieséses szakaszban még kiélezettebb mérkőzések várhatóak, ahol már nem lehet hibázni (vereséget szenvedni). Minél inkább haladunk a döntő felé, annál magasabbak a jegyárak, annál nagyobb hasznot realizálhatnak a magasabb jegyárakkal a szervezők - így érhetik el a boldogság maximalizálását. Megjegyzendő, hogy minden mérkőzés 3 * 20 perces és lehet, hogy a csoportkörben játszanak is egymás ellen azon nemzetek, akik majd a döntőt fogják vívni. Ennek ellenére a csoportkörös jegyár szignifikánsan alacsonyabb, mint a döntőbeli jegyár, így azt gondoljuk, a végjáték izgalma és a győztes kilétéhez való egyre közelebb kerülés az oka annak, hogy magasabb jegyárakat lehet meghatározni, aminek következtében nagyobb hasznot (boldogságot) realizálhatnak a szervezők. Mill filozófiájában a magasabb rendú élvezetekre koncentrál. Ezen utilitarista igazságossági elv alapján az alacsonyabb és magasabb rendű élvezetek között úgy tudnak a szervezők különbséget tenni a jegyárakkal kapcsolatban, hogy „magasabb rendü élvezetnek” tekintik egy egyenes ági kieséses mérkőzést egy csoportmérkőzéshez képest. Hiszen az egyenes ági kieséses mérkőzés adta élvezet (nincs hibázási lehetőség, legjobb 8 nemzet közötti részvétel, közeledik a döntőhöz vezető út vége) erősebb és hosszabban is tartó, mely boldogsághoz vezet. A szervezők ezért a magasabb rendű élvezetért kérik el a csoportkörhöz képesti magasabb jegyárakat.

A libertarianizmus értékvilága is képviselteti magát az egyenes ági kieséses szakaszban a mérkőzésekre szóló jegyárak kapcsán. A szabadelvűséget a csoportkörhöz hasonlóan itt is a „kereslet-kínálat párra” lehet alapozni korlátozásmentes piacként, nincs egy államilag szabályozott piac. Szabad jogként a szervezők akármekkora jegyárakat megadhatnak, nekik is az a lényeg, hogy elkeljenek a jegyek, így az árképzésük összefügg a kereslet-kínálattal. Ennek függvényében érezték úgy, hogy a magasabb árú jegyek az egyenes ági kie- 
séses szakaszra el fognak kelni, hiszen az eredmények alapján csoportonként 4-4 nemzet jut a negyeddöntőbe, várhatóan a világ aktuális 8 legjobb csapata (amely nem függ össze feltétlenül az aktuális világranglista-helyezéssel) - amiért „jogosan” el lehet kérni magasabb jegyárakat. A maximális jegyár (rezervációs ár) meghatározása itt is kulcskérdés a telt ház és haszonmaximalizálás érdekében: ne legyen a meghatározott összeg nagyobb a szurkolók rezervációs áránál, azaz annál az összegnél, amelyet még hajlandóak kifizetni egy jegyért.

Az egalitarianista elv is megfigyelhető a jegyárakkal kapcsolatban az egyenes ági kieséses rendszerben, hiszen van egyenlőség - azonban ismét csak részleges. Azért csak részleges egyenlőségről tudunk beszélni, mert az egyenes ági kieséses szakasz nem minden mérkőzésére ugyanolyan összegűek a jegyárak, azonban „fordulónként" megegyezik, egy kivétellel (az elődöntő után más a 3. helyért zajló mérkőzés és a döntő jegyára). Ha megvizsgáljuk az 1. táblázatot, az összes negyeddöntős mérkőzés jegyára megegyezik. Azaz nincs különbség (még kategóriák között sem), pedig nem azonos erősségű párharcok várhatóak (a sport természete miatt nem is lehetnek: bizonytalan végkimenetel, fordulatosság stb.), mégis látatlanban ugyanazok a jegyárak. Ugyanez érvényes az elődöntőkre is. Ahol nem figyelhető meg egyenlőség, az a 3. hely és a döntő köre. Ezzel a kettő mérkőzéssel zárul a világbajnokság, a sportesemény legjobb 4 csapata játszik, azonban a jegyárakban hatalmas a különbség. Míg az előző fordulóban az elődöntőben egalitarianista elvek alapján ugyanakkora összegért lehetett látni ezen csapatokat, addig az elődöntők veszteseinek és győzteseinek mérkőzése között jegyárak tekintetében szignifikáns a különbség (II. kategóriás jegyárak esetében több mint kétszeres) - azaz nem egyenlően kezelik a csapatokat az elődöntők után, a győztesek mérkőzésére jóval magasabbak a jegyárak (pedig elképzelhető, hogy hátrébb szerepelnek a világranglistán, és a csoportkörben fordított végeredmény született).

Pozitív diszkrimináció az egyenes ági kieséses rendszerben a jegyárak tekintetében nincs jelen, amennyiben a "sandeli elveket" alkalmazzuk: a sokszínűség előmozdítása érdekében nincsenek más jegyárak, valamint a hazai válogatott, Szlovákia sincsen (pozitívan) megkülönböztetve, hiszen nem tudjuk, melyik mérkőzéseket fogják játszani (ha egyáltalán bejutnak az egyenes ági kieséses szakasz adott fordulójába). Pozitív diszkrimináció egyedül ott figyelhető meg, hogy párhuzamosság van az emelkedő jegyárak és az egyre alacsonyabb versenyzői csapatlétszám között, akik a végső győzelemért küzdenek (kivétel a bronzmérkőzés, erre később kitérve). Azaz amikor a negyeddöntő után megfeleződik a mezőny, a jegyárak kétszeresek lesznek (l. kategóriás jegyárakat vizsgálva, II. kategória esetében több mint kétszeresek a jegyárak), azaz a továbbjutók, „elért eredmények alapján jobbak, kiválóbbak” pozitívan vannak megkülönböztetve. Ugyanez igaz a következő „felezésre”, amikor az elődöntős 4 csapatból csak 2 marad, és küzd a világbajnoki címért, ott is közel kétszeres az árkülönbség a jegyek között. A 3. helyezésért folyó mérkőzés azonban semmilyen szinten sincs pozitívan megkülönböztetve, sőt... Az elődöntős jegyáraknál is alacsonyabbak az árak a mérkőzésükre (pedig ugyanazon csapatok 
játszanak), szemben a döntővel, ahol több mint kétszeres a jegyárkülönbség (II. kategóriás jegyárakat vizsgálva). A jegyárak nyilván nincsenek összhangban a teljesítménnyel, ezt előre nem is lehetne tudni, azonban ennek részletes vizsgálatára nem térünk ki.

Ennél a résznél megemlítjük Rawls elméletét, ezen belül a „tudatlanság fátyla" mögötti döntést (Rawls, 1971), amely szerint döntenünk kell, melyik mérkőzésre szerzünk jegyeket - mit gondolunk, továbbjut-e egy adott csapat, és ha igen, csoportjából melyik pozícióban: hol, mikor és melyik másik válogatottal fog játszani. Nem tudjuk előre, így a jegyár meghatározása ebben az esetben igazságos a rawlsi elmélet szerint: a "tudatlanság fátyla" szerint döntünk, megveszünk-e egy belépőt, ha megvesszük: igazságosnak érezzük ez alapján a jegyárat.

\section{Következtetések: Léteznek igazságos jegyárak, és igazságosan határoz- zák meg a szervezők}

Összességében elmondhatjuk, egy sportesemény, azaz jelen esetben a jégkorong-világbajnokság (Világcsoport) és a jegyár-meghatározás téloszának mindenképpen meg kell felelni. Ezek teljesülése nélkül nem beszélhetünk igazságosságról. Megállapítottuk, hogy egy sportesemény, azaz jelen esetben a jégkorong-világbajnokság szervezők által meghatározott hivatalos jegyárai igazságosnak tekinthetőek: mindegyik tanulmányban vizsgált igazságosságelmélet megfigyelhető - csak attól függ, melyik igazságosságelméletet veszik figyelembe egy adott mérkőzések jegyáraival kapcsolatban a szervezők, és miért. Egy biztos, az alkalmazott igazságosságelméletnek az esemény téloszával is összhangban kell állnia, amely kizáró feltétel. El kell dönteni, hogy egy adott mérkőzés jegyárainak meghatározása esetén melyik a legindokoltabb igazságossági elmélet, és miért? Valamint bármely világbajnokság vagy verseny szervezők által meghatározott hivatalos jegyárai is tekinthetők igazságosnak, csak attól függ, melyik igazságosságelméletet alkalmazzák a szervezők adott sporteseménnyel kapcsolatban - a kizáró feltétel továbbra is és végig fennáll: az esemény téloszával összhangban kell állnia. Vannak olyan kizáró igazságosságelméletek a 2019-es jégkorong-világbajnokság jegyárainak meghatározása kapcsán, amelyek nem felelnének meg a télosznak, ilyen a méltányosság és a hendikep kérdésköre. Azaz alkalmazzunk méltányosságot a szomszédos országok esetében, vagy a gazdaságilag fejletlenebb országoknak adjunk előnyöket? Ez a versenysport téloszának nem felel meg, ezért sem alkalmazhatóak ezen elméletek a jegyárak meghatározásával kapcsolatban - ezért sem kerültek vizsgálat alá a fentiek a kutatás során, csak említés szintjén szerepelnek; azaz a kutatás során kizárólag „télosz-kompatibilis" igazságosság-elméletek lettek elemezve.

A versenysportra a télosszal összeegyeztethetően jogosan jellemző a meritokratikus és arisztotelészi kiválóságalapú szemlélet, amely az igazságosság alapja lehet. A hazai mérkőzésekre a jegyárak meghatározása azonban inkább 
utilitarista elvet követ. A 2019-es jégkorong-világbajnokság jegyáraival kapcsolatban megállapítható az egalitarianista és libertarianista igazságosság is. Azaz több igazságosságelmélet is megjelenik és érvényesül, azonban egyik igazságosságelmélet sem tud egyedüliként tökéletesen megvalósulni és egyértelműen érvényesülni, uralkodóvá válni a jégkorong-világbajnokság szervezői által meghatározott hivatalos jegyárakkal kapcsolatban. Számtalan további igazságossággal kapcsolatos kérdés merülhet fel a témában, a kérdés továbbra is az, melyik igazságosságelméletet fogadjuk el, és miért éppen azt követjük? Mi az igazságalapja? A kutatás során megállapíthatjuk, hogy nem teljesen meritokratikus és arisztotelészi kiválóságalapú a jegyár-meghatározási rendszer. A kutatásból kiderült, hogy szignifikánsan számít a jegyárak meghatározásában a jégkorongnemzetek világranglista-helyezése (amely által "kiválóbbak" a világranglistán hátrébb rangsorolt csapatoknál), azonban más igazságosságelméletek is szerepet játszanak az árképzésben.

Bebizonyítottuk, hogy az evolúciós alapeszmének, azaz a helyzethez megfelelő alkalmazkodásnak (szervezők által meghatározott, tapasztalatokból és igényekből kiinduló jegyárak) minden körülmények között teljesülnie kell befolyásolni az optimális jegyárakkal tudják a szervezők a nézettséget, elérve a kívánt célt: a telt házas mérkőzéseket. Az utilitarianizmus is képviselteti magát, hiszen a szervezők a legnagyobb hasznosság elvét követik, ezzel maximalizálva a boldogságot (és részben a rendezvény gazdasági megtérülését) - Mill „magasabb rendű élvezetei" a mérkőzések nyújtotta élvezetnél figyelhetőek meg, és ezzel indokolhatóak, miért magasabbak egyes mérkőzésekre (világranglistán előkelőbb helyezésű válogatottak meccseire vagy egyenes ági kieséses mérkőzésekre) a jegyárak. Ezen elmélet összefügg a libertarianizmussal - a legnagyobb hasznosság érdekében a "szabadelvű piacot”, azaz a kereslet-kínálat törvényeit veszik alapul: mekkora az a maximális összeg (rezervációs ár), amelyet a szurkolók hajlandóak fizetni egy jegyért, hogy élőben a helyszínen láthassák a csapatokat. Egalitariánus is a rendszer, hiszen több válogatott mérkőzésére is ugyanazok a jegyárak, valamint a csoportkör utáni egyenes ági kieséses rendszer fordulóira (negyeddöntők és elődöntők) is igaz a „jegyáregyenlőség” (kivéve a 3. hely és a döntő mérkőzés, amely között jelentős eltérés figyelhető meg az 1. táblázat alapján). Pozitív diszkriminációként a "sandeli elveket" nem figyeltük meg, azonban a csoportkör során a hazai csapat megkülönböztetését igen, amely pozitív diszkrimináció a csoportkör utáni, egyenes ági kieséses rendszerben már nem jelenik meg. Ezen fejezetnél megjelenhet Rawls elmélete a "tudatlanság fátyla” mögötti döntéssel (Rawls, 1971): melyik mérkőzésre szerezzünk jegyeket, mit gondolunk, továbbjut-e adott csapat, és ha igen, csoportjából melyik pozícióban, kivel fog megmérkőzni (vagy előre „látatlanban" veszünk a döntőre is belépőt, hátha bejut az általunk kívánt nemzet). Ezen elméletek a versenysport téloszának is mind-mind megfelelnek (Zimányi, Vermes, 2016), így igazságosnak is mondhatóak.

Minden jégkorong-világbajnokságon ugyanazok az igazságosságelméletek jelennek meg, és ugyanolyan formában, ugyanazon nemzetekre érvényesek? A 
válasz könnyen belátható, hogy nemleges. Az igazságosságelméletek filozófiaelméleti és gyakorlati háttere még lehet ugyanaz, azonban az egyenlőség elve a jegyárak kapcsán más és más nemzetekre vonatkozhat, nem beszélve a jelenlegi tanulmányban is vizsgált Csehország példáját, ahol a magasabb jegyárak (a házigazda Szlovákiához hasonlóan) földrajzi és társadalmi indokoltságot is mutatnak. Csehország mérkőzéseire a jegyárak másként alakulhatnak, ha nem Szlovákia vagy Csehország a jégkorong-világbajnokság házigazdája; kizárólag teljesítményalapú lehet a megítélésük. Az igazságosságelméletek lehetnek ugyanazok, azonban más és más elmélet jelenhet meg évről évre egy nemzetnél - például változhat a nemzeti válogatottak erőssége, világranglista-helyezése, így a helyszínen történő megnézésükre irányuló keresletük is (kivétel a hazai csapat, amelyre mindig nagyobb az érdeklődés, ennek identitással kapcsolatos okai lehetnek).

\section{Jövőbeni kutatási ötletek, lehetőségek, iránymutatás}

A téma továbbgondolásaként elemezni lehetne a következő világbajnokságok jegyárait igazságosságelméleti szempontból, mely nemzetek esetében hogyan változott, és miért, mi lehet a változás igazságosságelméleti alapja. Továbbá vizsgálni lehet más sportesemények hivatalos, szervezők által meghatározott jegyárait: például miben más, és miben hasonló más sportágakban (labdarúgás, tenisz, atlétika stb.) a világbajnokságok vagy világesemények jegyárainak képzése? Mi a különbség az olyan sportágakhoz képest, amelyek nem csoportmérkőzéssel kezdődnek, hanem egyből egyenes ági kieséses rendszerrel, ahol nem lehet hibázni - azaz egy vereséggel is búcsúzni lehet a további küzdelmektől? Illetve van-e különbség az egyéni és csapatsportok jegyárképzési rendszere és igazságossági elve között? Valamint ha Magyarország kvalifikálta volna magát a 2019-es (Világcsoport) világbajnokságra, akkor a magyar válogatottnak milyen jegyárat határoztak volna meg a szervezők, és ezt milyen igazságossági elv alapján tették volna? Továbbá elemezni lehet részletesen a viszonteladói felfogást: miért tér el, és sok esetben miért magasabb egy viszonteladói jegyár az eredeti, szervezők által meghatározott jegyárhoz képest? Illetve mikor csökkenhetnek a viszonteladói jegyárak? Ők mi alapján érzik igazságosnak az árképzést? Kizárólag utilitarista szempontok játszanak szerepet? A kutatás adott mérkőzésekre szóló belépőjegyekre terjedt ki, de mi a helyzet a bérletekkel? A bérletárak meghatározása miként lenne igazságos? Milyen elv szerint igazságos egy nemzet összes csoportmérkőzésére szóló jegyár megállapítása? Valamint mi lehet a különbség a két helyszín (Pozsony és Kassa) jegyáraival kapcsolatban, milyen igazságossági aspektus alapján tesznek különbséget a szervezők? 


\section{Felhasznált szakirodalom}

Aristotle's, (2011): Nicomachean Ethics. Chicago and London: The University of Chicago Press.

Bentham, J. (1996): Introduction to the Principles of Morals and Legislation. University Press, Oxford.

Darwin, C. (2015): A fajok eredete. Typotex, Budapest.

Friedman, M. (1962): Capitalism and Freedom. University of Chicago Press, Chicago.

Földesiné Szabó Gyöngyi, Gál Andrea, Dóczi Tamás: Sportszociológia. Budapest, Semmelweis Egyetem Testnevelési és Sporttudományi Kar (TF). 2010

Maclntyre, A. (2007): After virtue (3rd ed.). University of Notre Dame Press, Notre Dame, Indiana.

Mill, J. S. (1989): On Liberty. University Press, Cambridge.

Mill, J. S. (1979): Utilitarianism. George Sher, ed. Hackett Publishing.

Rawls, J. (1971): A Theory of Justice. Mass.: The Belknap Press of Harvard University Press, Cambridge.

Sandel, M. J. (2009): Justice. What's the Right Things to Do? Farrar, Straus and Giroux, New York.

Simon, R. L., Torres, C. R., Hager, P. F (2015): Fair play the ethics of sport (4th ed.). Westview Press, Colorado.

Warburton, N. (2012): A Little History of Philosophy. Yale University Press, New Haven.

Zimányi, R. (2016): Sportolók és sportegyesületek közötti minőségi szerződéskötések és átigazolások. In: Keresztes Gábor (szerk.), Tavaszi Szél 2016 = Spring Wind 2016. Tanulmánykötet. IV. kötet: Pszichológia és neveléstudomány, sporttudomány, szociológia és multidiszciplináris társadalomtudomány, történelem- és politikatudomány (p. 211-219).

Zimányi R. G., Géczi G. (2018/a): Justice at Sport Clubs According to the Theory of Utilitarianism and Libertarianism PHYSICAL CULTURE AND SPORT STUDIES AND RESEARCH 77:(1) pp. 55-60.

Zimányi R. G., Géczi G. (2018/b): A Grand Slam tenisztornák igazságossága a versenyzők és a kiemelések aspektusi alapján - A 2017-es US Open férfi egyéni bajnokságának esettanulmánya. MAGYAR SPORTTUDOMÁNYI SZEMLE 19: 4 (76) pp. 60-67., 8 p.

Zimányi, R., Vermes, K. (2016): Happy Sport Clubs. A. Gál, J. Kosiewicz \& T. Sterbenz (Eds), Sport and Social Sciences with Reflection on Practice. Warsaw: AWF-ISSSS, pp. 117-128. 
http://2019.iihfworlds.com/en/tickets/(letöltés dátuma: 2018. szeptember 28.) https://www.iihf.com/en/events/2019/wm/tournamentinfo/3951/tournamentinfo (letöltés dátuma: 2018. november 22.)

https://www.iihf.com/en/tournaments (letöltés dátuma: 2018. november 22.)

https://www.iihf.com/en/worldranking (letöltés dátuma: 2018. november 21.) 